\title{
THE DISTRIBUTION OF ACID MUCOPOLYSACCHARIDES IN COHN FRACTIONS OF HUMAN PLASMA PROTEINS ${ }^{1}$
}

\author{
By GRACE P. KERBY \\ (From the Department of Medicine, Duke University School of Medicine, Durham, N. C.)
}

(Submitted for publication October 11, 1957 ; accepted January 2, 1958)

Acid mucopolysaccharides behaving similarly to chondroitin sulfate on paper electrophoresis and paper chromatography have been demonstrated previously in human leukocytes $(1,2)$. A chondroitin sulfate-like substance has been recovered also from blood platelets of rats (3). A similar substance has been demonstrated in human urine $(4,5)$, and this substance has been identified tentatively as chondroitin sulfate A or C (6). Delay in recognizing the occurrence of chondroitin sulfate in plasma was occasioned by failure initially to recognize that the acid mucopolysaccharides of plasma appear to be in combination with plasma proteins.

Chondroitin sulfate-like substances have been recovered from human plasma now in a number of laboratories, including our own, and reports concerning recoveries and quantitative levels have appeared (7-9). The acid mucopolysaccharides are recoverable from plasma protein precipitated in the euglobulin fraction. The present report deals with a survey of Cohn fractions of plasma proteins for acid mucopolysaccharide content. Chief occurrence of acid mucopolysaccharides was noted in Fractions III and IV-1.

\section{METHODS}

Human plasma protein Cohn Fractions I, II, III, IV-1, IV-4 and V were generously furnished for the study by E. R. Squibb and Sons through the kind cooperation of Dr. J. N. Ashworth of the American National Red Cross. Duplicate $100 \mathrm{mg}$. samples were tested for acid mucopolysaccharide content by a combination and modification of the methods of Badin, Schubert, and Vouras (7) and DiFerrante (5). In brief, the method consisted of enzymatic hydrolysis and defatting ${ }^{2}$ of the protein fraction, precipitation of acid

1 This work was supported by grants from the $\mathrm{Na}$ tional Institute of Arthritis and Metabolic Diseases, United States Public Health Service, and the American Heart Association.

2 Ethanol-precipitated protein material was finely suspended in $3 \mathrm{ml}$. of $0.1 \mathrm{~N} \mathrm{HCl}$. Crystalline pepsin (National Biochemicals Co.), $6 \mathrm{mg}$. in $1.0 \mathrm{ml}$. of $0.1 \mathrm{M}$ mucopolysaccharides by the use of cetyl trimethyl ammonium bromide (5), and measurement of acid mucopolysaccharides as hexuronic acid by the carbazole method of Dische (10). The materials recovered were compared on paper chromatography (4) to commercial chondroitin sulfate (General Biochemicals, Inc.) and to heparin (Liquamin ${ }^{\circledR}$ Sodium, Organon, Inc.).

Since acid mucopolysaccharides and lipoproteins were found to occur chiefly in the same fractions, an attempt was made to determine whether the occurrence of acid mucopolysaccharides was influenced by lipid linkages. Cohn Fractions II, ${ }^{3}$ III and IV-1 were subjected to lipid extraction by several methods: (A) ethanol-ether $(3: 1)$ in a one-phase system at $60^{\circ} \mathrm{C}$. for three 10 minute periods, (B) $n$-butanol in a two-phase system with water at room temperature overnight (11), (C) $n$-butanol in a one-phase system at $-15^{\circ} \mathrm{C}$. (11). In each instance the lipid solvent layer was removed to tared vessels for drying and weighing of lipid residues, the residue was extracted in water which was then removed and subjected to rotary evaporation at $46^{\circ} \mathrm{C}$. and measured for hexuronic acid content, and the residue itself was subjected to enzymatic hydrolysis and precipitation with cetyl trimethyl ammonium bromide and measurement of hexuronic acid content.

\section{RESULTS}

Paper chromatographic studies (Figure 1A) of material derived from $100 \mathrm{mg}$. samples of Frac-

phosphate buffer, $\mathrm{pH}$ 5.01, was added. Final $\mathrm{pH}$ was about 2.0. Digestion was visibly rapid and was continued for 90 minutes in a $37^{\circ} \mathrm{C}$. water bath. Ethanol precipitation (from 80 per cent ethanol after addition of $0.18 \mathrm{ml}$. of 25 per cent sodium chloride) was repeated, and the precipitate was then extracted with $10 \mathrm{ml}$. of diethyl ether for 15 minutes, centrifuged and taken up in $4 \mathrm{ml}$. of $0.1 \mathrm{M} \mathrm{pH} 7.6$ phosphate buffer. Crystalline trypsin (50 per cent magnesium sulfate, National Biochemicals Co.), $4 \mathrm{mg}$. in $1.0 \mathrm{ml}$. of $0.01 \mathrm{~N} \mathrm{HCl}$, was added. Final $\mathrm{pH}$ was about 7.0. The material was then transferred quantitatively to Visking $18 / 32$ inch cellulose casing and dialyzed against $100 \mathrm{ml}$. of $0.1 \mathrm{M}$ phosphate buffer $\mathrm{pH} 7.6$ in a $125 \mathrm{ml}$. Erlenmeyer flask on a New Brunswick Gyrotory Shaker at room temperature for four hours, with one change of buffer at two hours. The material was diluted to $10 \mathrm{ml}$. with demineralized water prior to the next precipitation step.

${ }^{3}$ Fraction II was included as a control in all three methods. 


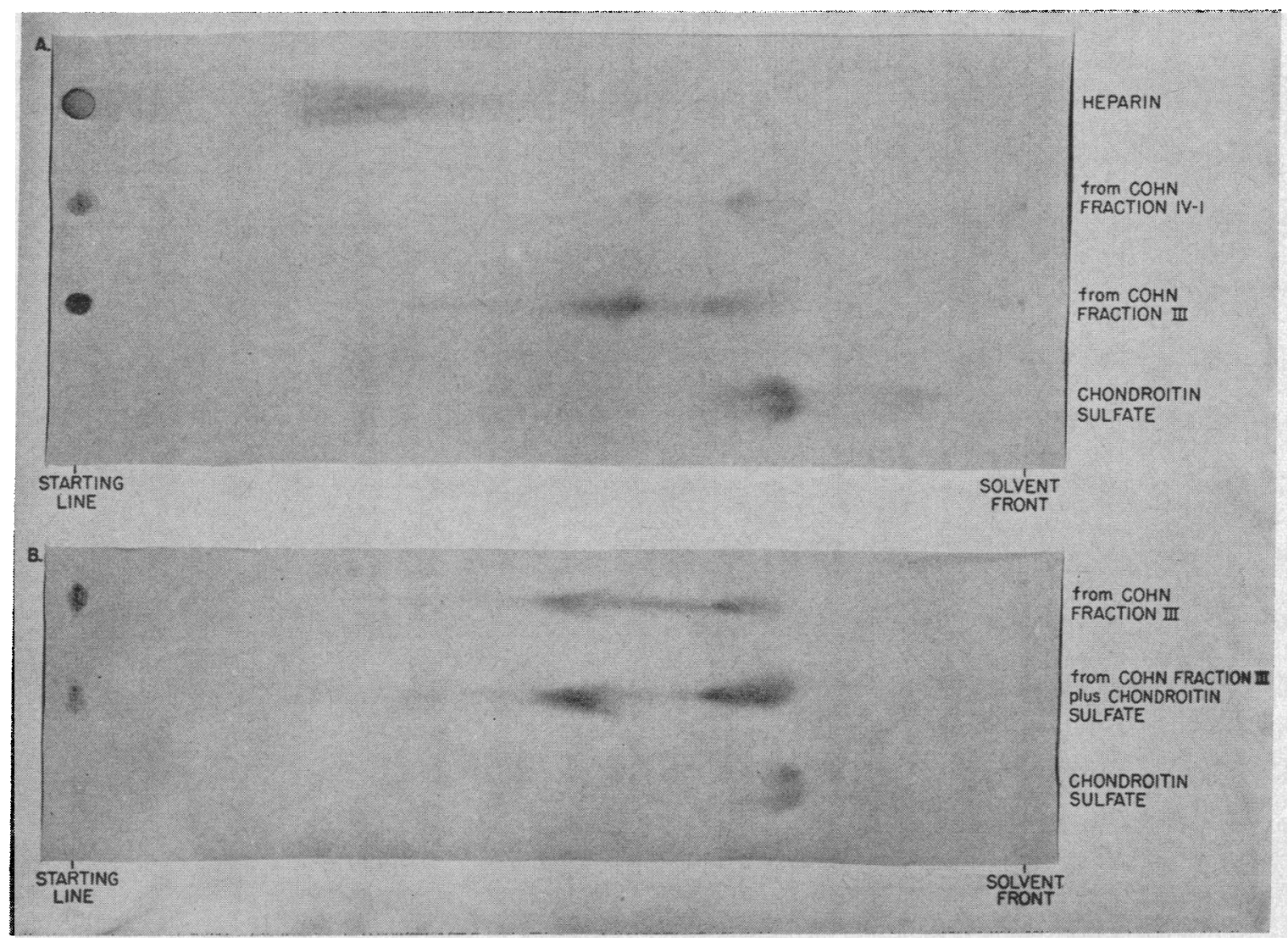

Fig. 1. Filter Paper Chromatograms of Hexuronic Acid-Containing Polysaccharides From Cohn Fractions of Human Plasma

Solvent 48 per cent ethanol in $\mathrm{pH} 7.25 \mathrm{M} / 15$ phosphate buffer.

All spots were intensely metachromatic except those at the starting line of the Cohn fraction materials, where the dark spots were predominantly insoluble material taking a bluish stain, showing no definite metachromasia in Fraction III material and only slight metachromasia in Fraction IV-1 material.

tions III and IV-1 showed two chief metachromatic components which have been seen also in studies on derivatives of the euglobulin fraction of fresh human plasma, using an ethanol-phosphate system. One component moved slightly behind the chief component of chondroitin sulfate, and the slower rate may have been due to a slight difference in the viscosity of the material inasmuch as a mixture of chondroitin sulfate with the material failed to resolve into two distinct spots in this position (Figure 1B). A second chief component moved much more slowly than chondroitin sulfate but faster than heparin; an eluate of this component showed on rechromatography the same slow spot as before as well as a small amount of the faster-moving material which resembled chondroitin sulfate; the tailing effect evident in Figure 1A and $B$ was absent in chromatograms of eluates. A third minor metachromatic component moved with the solvent front; rechromatography of an eluate of this component revealed a single spot with mobility resembling that of chondroitin sulfate. Metachromatic material was not demonstrated in chromatograms of Fractions I and IV-4, using material derived from $100 \mathrm{mg}$. of the respective fractions. However, a concentrate derived from $400 \mathrm{mg}$. of Fraction I did reveal a small amount of definitely metachromatic material which moved slightly off the starting line in an ethanol-phosphate system, in the area of heparin mobility. It was not possible to determine whether the slow mobility was truly identical with that of heparin or whether mobility was slowed by the comparatively and considerably greater amount of extraneous material present in the large amount of material concentrated. Separation was insufficient to per- 
TABLE I

Results of extraction of Cohn fractions with lipid solvents followed by aqueous extraction of the residue

\begin{tabular}{|c|c|c|c|c|c|c|}
\hline \multirow[b]{2}{*}{ Extraction procedure* } & \multicolumn{3}{|c|}{$\begin{array}{l}\text { Hexuronic acid ( } \mu \mathrm{g} \text {. per } \\
100 \mathrm{mg} \text {. of original } \\
\text { fraction) }\end{array}$} & \multicolumn{3}{|c|}{$\begin{array}{l}\text { Weight of lipids extracted by } \\
\text { solvent (mg. per } 100 \mathrm{mg} \text {. } \\
\text { of original fraction) }\end{array}$} \\
\hline & A & B & C & $\mathrm{A}$ & B & $\mathrm{C}$ \\
\hline \multirow{2}{*}{$\begin{array}{l}\text { Fraction III (Total APS) } \\
\text { Lipid solvent extract } \\
\text { Subsequent aqueous extract } \\
\text { Residue, APS }\end{array}$} & \multicolumn{3}{|c|}{$(21.8)$} & \multirow[b]{2}{*}{14.5} & \multirow[b]{2}{*}{14.8} & \multirow[b]{2}{*}{5.3} \\
\hline & $\begin{array}{c}0 \\
22.5\end{array}$ & $\begin{array}{l}0 \\
\dagger\end{array}$ & $\begin{array}{c}0 \\
17.8\end{array}$ & & & \\
\hline \multirow{2}{*}{$\begin{array}{l}\text { Fraction IV-1 (Total APS) } \\
\text { Lipid solvent extract } \\
\text { Subsequent aqueous extract } \\
\text { Residue, APS }\end{array}$} & \multicolumn{3}{|c|}{$(16.0)$} & \multirow{2}{*}{22.3} & \multirow{2}{*}{20.3} & \multirow{2}{*}{19.5} \\
\hline & $\begin{array}{r}5.6 \\
11.5\end{array}$ & $\begin{array}{c}0 \\
15.4\end{array}$ & $\stackrel{\dagger}{\dagger}$ & & & \\
\hline Fraction II (Total APS) & \multicolumn{3}{|c|}{$(0)$} & \multirow{3}{*}{0.3} & \multirow{3}{*}{$\dagger$} & \multirow{3}{*}{0.1} \\
\hline Lipid solvent extract & & & & & & \\
\hline $\begin{array}{l}\text { Subsequent aqueous extract } \\
\text { Residue, APS }\end{array}$ & $\begin{array}{l}0 \\
0\end{array}$ & $t$ & $\begin{array}{l}0 \\
0\end{array}$ & & & \\
\hline Lipid solvent controls & & & & 0 & 0.5 & 0.5 \\
\hline
\end{tabular}

* A, ethanol-ether $(3: 1)$ in a one-phase system at $60^{\circ} \mathrm{C}$. for three 10 minute periods; $\mathrm{B}, n$-butanol in a two-phase system with water at room temperature overnight (11); C, $n$-butanol in a one-phase system at $-15^{\circ} \mathrm{C}$. (11).

+ No determination possible for technical reasons. The residue of Fraction III by Method B and the evaporated aqueous phase of Fraction IV-1 by Method C presented blanks which were too dark to be visually acceptable, and no readings were made. Fraction II, which was included as a control in all three methods, could not be separated satisfactorily in the two-phase system with $n$-butanol but was carried through the other two extraction procedures satisfactorily.

mit elution of the area and rechromatography. Material derived from $400 \mathrm{mg}$. of Fraction IV-4 showed only a faint spot still slower in its mobility than the slow component of Fractions III and IV-1 and probably metachromatic; its faintness was such as to preclude photography or a more definite descriptive statement.

Hexuronic acid determinations showed no detectable color in material derived from Fractions II and V and trace amounts in Fractions $\mathrm{I}$ and IV-4 (equivalent to 3.9 and $10.7 \mu$ g., respectively, of hexuronic acid per $100 \mathrm{mg}$. of weighed samples of the fractions). Fractions III and IV-1 showed larger amounts (21.8 and $16.0 \mu \mathrm{g}$., respectively). The presence of contaminating mucoprotein or glycoprotein was shown by the relatively high hexosamine (2) values obtained on analysis of the materials derived from Fractions III and IV-1 (60.2 and $35.6 \mu$ g., respectively). The data were regarded as useful, therefore, only insofar as they offered collateral support for the observations made of metachromatic materials on paper chromatography and as they furnished a baseline for the studies involving lipid extractions.

Results of lipid extraction procedures are summarized in Table I. Extraction of Fraction III with lipid solvents failed to release demonstrable acid mucopolysaccharides to subsequent aqueous extract by any of the extraction methods used, and subsequent analysis of the residue revealed no loss of original acid mucopolysaccharide content. Extraction of Fraction IV-1 with ethanol-ether at $60^{\circ} \mathrm{C}$. (Method A) was followed by demonstration of a small amount of hexuronic acid in the subsequent aqueous extract and a slight decrease in the apparent acid mucopolysaccharide content of the residue. A similar result was probably observed using $n$-butanol at $-15^{\circ}$ C. (Method C); analysis of the aqueous extract was unsatisfactory (see Table I); the residue showed a decrease in acid mucopolysaccharide content as in Method A. The extent to which any of the methods used was successful in breaking the lipoprotein bond of the partially denatured Fractions III and IV-1 is open to doubt. The amount of lipid demonstrated in the lipid solvent extracts was less by weight than the amount which has been demonstrated (12) in lipoprotein fractions prior to drying and subsequent denaturation.

\section{DISCUSSION}

A chief site of occurrence of acid mucopolysaccharides in human plasma Cohn fractions has been shown in the present study to be those frac- 
tions (III and IV-1) which contain the major portion of the plasma lipoproteins. Paper chromatographic studies of the metachromatic material recovered revealed at least two components, one of which resembled the chief component of commercial chondroitin sulfate and may possibly be the chondroitin sulfate A component described by Schiller and Dewey (8). The other component was not identified but did not resemble either heparin or components of commercial chondroitin sulfate. Both components appeared identical to those observed in the acid mucopolysaccharidelike material recoverable from the euglobulin fraction of fresh human plasma.

Attempts to break the lipid-protein bond of Fractions III and IV-1 by several procedures were only partially successful as judged by weight of lipids recovered from the lipid solvent extracts. Within the limits of the methods used and to the extent that lipid-protein bonds were severed, release of acid mucopolysaccharides for subsequent aqueous extraction could not be demonstrated from Fraction III ; a small amount may have been released from Fraction IV-1. This could indicate that the hexuronate-containing polysaccharides were for the most part bound to lipids which remained bound to proteins despite the extraction methods employed. It could also indicate the possibility of binding of acid mucopolysaccharides to a protein moiety which could be lipoprotein or could be other protein fortuitously present in the fractions. The present study fails to confirm or deny an affinity between acid mucopolysaccharides and lipoproteins. It does demonstrate the possibility of a bond between the two classes of substances in that they coincide in their chief site of occurrence in plasma protein fractions.

\section{SUM MARY}

1. Cohn fractions of human plasma proteins have been investigated to determine the predominant site of occurrence of the acid mucopolysaccharides which can be demonstrated regularly in the euglobulin fraction of human plasma. By the methods employed, predominant occurrence was in Fractions III and IV-1, Fraction III showing the larger amount.

2. Paper chromatographic studies of the acid mucopolysaccharide material recovered from Frac- tions III and IV-1 demonstrated two chief metachromatic components. One component resembled the chief component of commercial chondroitin sulfate in its mobility. A slower component was unidentified.

3. Attempts to confirm or deny a chemical or physical binding between the hexuronate-containing polysaccharides and the lipoproteins of Fractions III and IV-1 were inconclusive.

\section{ACKNOWLEDGMENT}

The technical assistance of Mrs. Nancy Langley is gratefully acknowledged.

\section{REFERENCES}

1. Bassiouni, M. The estimation of heparin and similar substances in human blood and tissues using a combined biological and colorimetric method with paper electrophoretic studies. J. clin. Path. 1954, 7, 330.

2. Kerby, G. P. The occurrence of acid mucopolysaccharides in human leukocytes and urine. J. clin. Invest. 1955, 34, 1738.

3. Odell, T. T., Jr., and Anderson, B. Isolation of a sulfated mucopolysaccharide from blood platelets of rats. Proc. Soc. exp. Biol. (N. Y.) 1957, 94, 151.

4. Kerby, G. P. The excretion of glucuronic acid and of acid mucopolysaccharides in normal human urine. J. clin. Invest. 1954, 33, 1168.

5. DiFerrante, N., and Rich, C. The determination of acid aminopolysaccharide in urine. J. Lab. clin. Med. 1956, 48, 491.

6. DiFerrante, N., and Rich, C. The mucopolysaccharide of normal human urine. Clin. chim. Acta 1956, 1, 519.

7. Badin, J., Schubert, M., and Vouras, M. Plasma polysaccharide fraction containing uronic acid, in normal subjects and in patients with rheumatoid arthritis. J. clin. Invest. 1955, 34, 1317.

8. Schiller, S., and Dewey, K. F. Isolation of chondroitin sulfuric acid from normal human plasma. Fed. Proc. 1956, 15, 348.

9. Bollet, A. J., Seraydarian, M. W., and Simpson, W. F. Acid mucopolysaccharides in normal serum. J. clin. Invest. 1957, 36, 1328.

10. Dische, Z. A new specific color reaction of hexuronic acids. J. biol. Chem. 1947, 167, 189.

11. Morton, R. K. Separation and purification of enzymes associated with insoluble particles. Nature (Lond.) 1950, 166, 1092.

12. Oncley, J. L., and Gurd, F. R. N. The lipoproteins of human plasma (Table I, Composition of various purified plasma lipoproteins) in Blood Cells and Plasma Proteins: Their State in Nature, J. L. Tullis, Ed. New York, Academic Press Inc., 1953, p. 338. 